
n. 1, p. 88-92, março 2003.

\title{
Desiccation effects on germination and vigor of King palm seeds
}

\author{
Cibele C. Martins ${ }^{1}$; Marilene L. A. Bovi ${ }^{2}$.João Nakagawa ${ }^{1}$
}

${ }^{1}$ FCA, UNESP, Depto. Produção Vegetal, C. Postal 237, 18.603-970, Botucatu-SP; E-mail: cibele@ fca.unesp.br; ${ }^{2}$ IAC, C. Postal 28, 13.001-970 Campinas-SP; E-mail: mlabovi@cec.iac.br

\begin{abstract}
The desiccation tolerance of Archontophoenix alexandrae (Wendl. \& Drude) seeds was determined and the most sensitive vigor test for assessing seed deterioration of this species was identified. Mature fruits were harvested in the palm collection of the Instituto Agronomico in Campinas, Brazil. Depulped fruits were transported in impermeable packages to the Faculdade de Agronomia in Botucatu, where the seeds were dried. As the seed moisture decreased, germination, seedling length, electrical conductivity and moisture were measured. The seeds of $A$. alexandrae are recalcitrant, with high germination percentage (over 67\%) when undried (47\% seed moisture). Lowering seed moisture below $31.5 \%$ reduced the germination rate significantly $(<52.5 \%)$. Total germination failure was observed when seed moisture reached $15.1 \%$. The electrical conductivity was the most sensitive vigor test to identify seed deterioration.
\end{abstract}

Keywords: Archontophoenix alexandrae, Alexandra palm, seed deterioration, electrical conductivity, recalcitrance, desiccation tolerance, critical moisture, lethal moisture.

\section{RESUMO}

Efeitos da dessecação sobre a germinação e o vigor de sementes de palmeira real australiana

Determinou-se a tolerância ao dessecamento de sementes de Archontophoenix alexandrae (Wendl. \& Drude) e identificou-se o teste de vigor mais sensível para avaliar a deterioração de sementes nessa espécie. Frutos maduros foram colhidos na coleção de palmeiras do Instituto Agronômico em Campinas. Os frutos despolpados foram transportados em embalagem impermeável para a UNESP em Botucatu, onde as sementes foram secas a diferentes intervalos de tempo. Foram avaliados teor de umidade, germinação, comprimento da plântula e condutividade elétrica. Os resultados sugerem que sementes de A. alexandrae são recalcitrantes, com alta porcentagem de germinação (acima de 67\%) quando não desidratadas (47\% de umidade). Teores de água inferiores a 31,5\% reduziram significativamente a taxa de germinação $(<52,5 \%)$. Perda total da capacidade germinativa foi observada em sementes com $15,1 \%$ de umidade. Dentre os testes de vigor empregados, aquele que avalia a condutividade elétrica da água de embebição foi o mais sensível para a identificação da deterioração da semente em resposta à dessecação progressiva do lote em estudo.

Palavras-chave: Archontophoenix alexandrae, seafortia, palmeira real australiana, recalcitrante, deterioração de sementes, condutividade elétrica, umidade crítica, umidade letal.

(Recebido para publicação em 06 de fevereiro de 2002 e aceito em 26 de novembro de 2002)

\begin{abstract}
A rchontophoenix alexandrae (Wendl. \& Drude), commonly known as King palm, Alexandra palm or Seafortia palm, is endemic to the tropical forests of east Australia. It produces heart-ofpalm or palmito of the noble type, with higher quality and superior flavor compared to that of Euterpe oleracea Mart. (açaí, or açaizeiro), which supplies more than $80 \%$ of the palmito traded in the international market (Bovi, 1998a).

Since 1990, the demand for seeds and seedlings of the King palm for commercial cultivation, aiming at heartof-palm production, has been increasing (Bovi, 1998b). Thus, information about seed physiology and the germination process is necessary for the development of seed production and conservation technologies for this palm. Seeds of other species from the Palmae family, such as Elaeis guineensis Jacq.,
\end{abstract}

Oreodoxa regia $\mathrm{HBK}$, Euterpe edulis Mart., E. oleracea Mart. and E. espiritosantensis Fernandes, present conservation problems, and are classified as recalcitrant, due to the high sensitivity to dehydration, (Ellis et al., 1991; Araújo et al., 1994; Andrade \& Pereira, 1997; Martins et al., 1999 ab).

Moisture is a decisive factor in maintenance of recalcitrant seed quality during storage. In these seeds, the subcellular water is strongly associated with macromolecular surfaces, assuring the stability of membranes and macromolecules. Water loss during the drying process causes a series of metabolic alterations, acting on the control of growth regulators, amount and types of proteins and sugars, presence of free radicals, physical water status, among others (Pammenter \& Berjak, 1999), resulting in the on-set of the deterioration process.
Recalcitrant seeds lose viability when moisture levels are lower than those considered critical. When seed moisture is at or below the levels considered lethal, there is a total loss of viability (Probert \& Longley, 1989; Pritchard, 1991; Hong \& Ellis, 1992).

Recalcitrant seed sensitivity to dehydration depends on species, drying rate and drying temperature. In palms, critical and lethal moistures are relatively high, varying from 38 to $27 \%$ (Ferreira \& Santos, 1992; Andrade \& Pereira, 1997; Martins et al., 1999 abc) and from 22 to $12 \%$ (Ferreira \& Santos, 1992; Andrade \& Pereira, 1997; Martins et al., 1999 abc), respectively. Knowledge of the critical and lethal moisture levels of a species is indispensable for planning and execution of seed drying and storage. Critical moisture content is considered 
Table1. Traits evaluated during King palm germination process.

\begin{tabular}{|c|c|c|c|c|c|c|c|c|c|}
\hline \multirow[t]{2}{*}{ Traits } & $\begin{array}{c}\text { Seed } \\
\text { moisture }\end{array}$ & $\begin{array}{l}\text { First } \\
\text { count }\end{array}$ & $\begin{array}{l}\text { Abnormal } \\
\text { seedlings }\end{array}$ & $\begin{array}{l}\text { Dead } \\
\text { seeds }\end{array}$ & $\begin{array}{c}\text { Total } \\
\text { germination }\end{array}$ & Plun & nule & Radicle & \multirow{2}{*}{$\begin{array}{c}\text { Electrical } \\
\text { conductivity } \\
(\mathrm{mS} / \mathrm{cm} / \mathrm{g})\end{array}$} \\
\hline & \multicolumn{4}{|c|}{$(\%)$} & & \multicolumn{3}{|c|}{ Length (mm) } & \\
\hline 1 & 47.5 & $61.2 \mathrm{a}$ & $11.2 \mathrm{bc}$ & $21.2 \mathrm{f}$ & $67.5 \mathrm{a}$ & 13.93 & $a$ & $32.98 \mathrm{a}$ & $14.78 \mathrm{e}$ \\
\hline 2 & 38.8 & $53.7 \mathrm{ab}$ & $5.0 \mathrm{~cd}$ & 28.7 ef & 66.2 a & 14.18 & $a$ & $29.78 a b$ & $19.30 \mathrm{de}$ \\
\hline 3 & 35.4 & $52.5 \mathrm{ab}$ & $5.0 \mathrm{~cd}$ & 30.0 ef & $65.0 \mathrm{a}$ & 13.83 & $a$ & $27.88 \mathrm{abc}$ & $21.40 \mathrm{~cd}$ \\
\hline 4 & 34.6 & $46.2 \mathrm{ab}$ & $3.7 \mathrm{~d}$ & 38.7 ef & $57.5 \mathrm{ab}$ & 11.45 & $a b$ & $24.68 \mathrm{abc}$ & $22.10 \mathrm{~cd}$ \\
\hline 5 & 31.5 & $46.2 a b$ & $20.0 \mathrm{a}$ & 27.5 def & $52.5 \mathrm{abc}$ & 9.50 & $\mathrm{bc}$ & $22.58 \mathrm{bcd}$ & $21.33 \mathrm{~cd}$ \\
\hline 6 & 30.1 & 30.0 bc & $17.5 \mathrm{ab}$ & $41.2 \mathrm{de}$ & $41.2 \mathrm{bcd}$ & 9.28 & $\mathrm{bc}$ & $18.63 \mathrm{~cd}$ & $22.50 \mathrm{~cd}$ \\
\hline 7 & 28.2 & $21.2 \mathrm{~cd}$ & $13.7 \mathrm{ab}$ & $48.7 \mathrm{~d}$ & 37.5 cde & 7.80 & $\mathrm{bc}$ & $14.20 \mathrm{de}$ & $23.78 \mathrm{~cd}$ \\
\hline 8 & 26.6 & $17.5 \mathrm{~cd}$ & $1.2 \mathrm{~d}$ & 77.5 bc & 21.2 efg & 7.40 & $\mathrm{bc}$ & $13.00 \mathrm{de}$ & $23.40 \mathrm{~cd}$ \\
\hline 9 & 24.8 & $10.0 \mathrm{~cd}$ & $1.2 \mathrm{~d}$ & $71.2 \mathrm{c}$ & 27.5 def & 8.88 & $\mathrm{bc}$ & $14.05 \mathrm{de}$ & $25.43 \mathrm{c}$ \\
\hline 10 & 23.9 & $12.5 \mathrm{~cd}$ & $3.7 \mathrm{~d}$ & $76.2 \mathrm{bc}$ & $20.0 \mathrm{fg}$ & 8.55 & $\mathrm{bc}$ & $13.75 \mathrm{de}$ & $24.85 \mathrm{~cd}$ \\
\hline 11 & 22.8 & $5.0 \mathrm{~d}$ & $0.0 \mathrm{~d}$ & $85.0 \mathrm{abc}$ & $15.0 \mathrm{fgh}$ & 8.03 & $\mathrm{bc}$ & $13.88 \mathrm{de}$ & $26.18 \mathrm{bc}$ \\
\hline 12 & 20.0 & $1.2 \mathrm{~d}$ & $0.0 \mathrm{~d}$ & $86.2 \mathrm{abc}$ & $13.7 \mathrm{fgh}$ & 6.00 & $\mathrm{C}$ & 6.10 ef & $30.73 b$ \\
\hline 13 & 17.8 & $0.0 \mathrm{~d}$ & $1.2 \mathrm{~d}$ & $92.5 \mathrm{ab}$ & $6.2 \mathrm{gh}$ & 7.48 & $\mathrm{bc}$ & 5.30 ef & $30.98 \mathrm{~b}$ \\
\hline 14 & 15.1 & $0.0 \mathrm{~d}$ & $0.0 \mathrm{~d}$ & $100.0 \mathrm{a}$ & $0.0 \mathrm{~h}$ & 0.00 & $d$ & 0.00 ef & $46.70 \quad a$ \\
\hline $\mathrm{CV}$ & 30.07 & 100.44 & 127.93 & 49.07 & 70.62 & 46.5 & & 64.94 & 30.95 \\
\hline means & 25.54 & 58.93 & 5.98 & 58.93 & 35.09 & 9.02 & & 16.91 & 25.24 \\
\hline
\end{tabular}

Means followed by the same letter in the column do not differ statistically by Duncan test at 0.05

to occur when a significant reduction in germination percentage is observed and lethal moisture content is determined by a complete lack of germination (Probert \& Longley, 1989; Pritchard, 1991; Hong \& Ellis, 1992).

For a more complete evaluation of the effect of the dehydration on the deterioration of recalcitrant seeds, it is customary to use vigor tests, such as germination speed, seedling growth rate, electric conductivity and enzymatic activity (Ferreira \& Santos, 1992; Araújo, et al., 1994; Andrade \& Pereira, 1997; Martins et al., 1999 abc). These tests are based on physical, physiological and biochemical characteristics of the seeds and are inexpensive, uncomplicated, rapid, objective, reproducible and, most of all, highly correlated to nursery or field performance. Vigor tests are frequently utilized because germination test results do not detect the progress of seed deterioration. They just indicate the status of the process at its final stage (Spears, 1995; International Seed Testing Association, 1993).

The objective of this study was to determine the effects of seed dehydration on germination and vigor and to identify which vigor test best assesses King palm seed deterioration.

\section{MATERIAL AND METHODS}

Mature fruits of King palm, with brilliant red coloration and starting to drop from the bunch (initial stadium of dispersion as reported by Bovi, 1998a), were collected manually from 10 individuals at the end of January 1999 (rainy season), at the Nucleo Experimental do Instituto Agronômico (IAC), Campinas, São Paulo, Brazil. The fruits were depulped by friction against a steel mesh screen under running water. The seeds were immediately transported in polyethylene bags $(20 \mu \mathrm{m}$ of thickness) to the Faculdade de Agronomia, Botucatu, São Paulo, Brazil. Damaged seeds or those below medium size $(0.69 \mathrm{~g})$ were eliminated.

The initial moisture of the seed lot was determined. Seeds were divided into 14 sub-lots, of similar weight. One of the sub-lots was maintained without drying (control). The other sub-lots were placed on trays inside a drying chamber with temperature and relative humidity of $28.52 \pm 2.5^{\circ} \mathrm{C}$ and $40 \pm 10 \%$, respectively. Samples were removed from the chamber every 12 hours.

Seed moisture was determined gravimetrically $\left(103 \pm 2^{\circ} \mathrm{C}\right.$ for 17 hours), following standard procedures (International Seed Testing Association, 1993), in three sub-samples of seven whole seeds removed at each drying period (0 to 156 hours).

A germination test was performed with four replicates of 20 seeds per treatment, under light $\left(78 \mu \mathrm{mol} \mathrm{s} \mathrm{s}^{-1} \mathrm{~m}^{-2}\right.$ for 8 hours) and alternating temperatures $\left(20-30^{\circ} \mathrm{C}\right)$, using sterilized $\left(120^{\circ} \mathrm{C}\right.$ for 12 hours) and humidified vermiculite in plastic boxes. Sowing took place with $2 / 3$ of each seed buried in the substrate. First count of germination, frequently used as a vigor test, was made 25 days after sowing. The germination test ended 47 days after sowing, when the percentages of normal and abnormal seedlings, as well as dead seeds, were calculated (International Seed Testing Association, 1993). Plumule and radicule lengths $(\mathrm{mm})$ were evaluated at the end of the germination test.

Membrane integrity was indirectly evaluated by means of the electrical conductivity test, using four replicates of 25 seeds per treatment. The seeds were weighted, placed in disposable plastic cups with $75 \mathrm{ml}$ of distilled water and left to soak at $25^{\circ} \mathrm{C}$ for 24 hours. After that, the electrical conductivity of the water was measured (Digimed multi- 

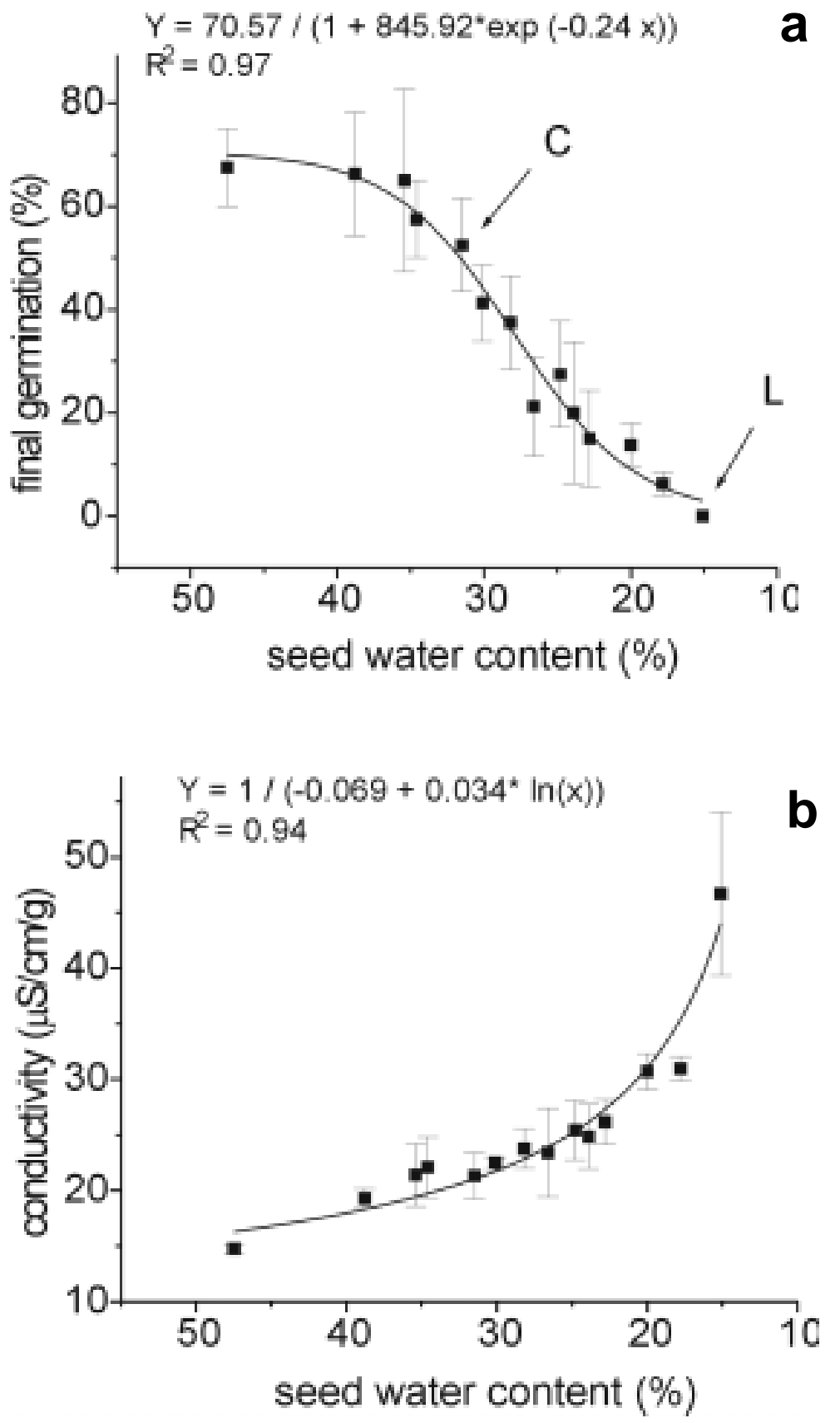

Figure 1. Relationship between (a) final germination and electrical conductivity (b) with seed moisture content of King palm (Archontophoenix alexandrae). Arrows show critical (C) and lethal (L) seed moistures. Vertical bars represent standard errors (b). Botucatu, UNESP, 1999.

cell conductivity meter, model Dm 31) and the values for each replication were expressed in $\mu \mathrm{S} \mathrm{cm}^{-1} \mathrm{~g}^{-1}$ of seed (fresh weight).

A completely randomized experimental design was used throughout, with four replicates and with the moisture contents of the seed as treatments. Variance and regression analyses of the data were performed using Microcal Origin, version 3.5.
Treatment means were compared by Duncan's test at 5\% probability level.

\section{RESULTS AND DISCUSSION}

The rate of water loss (Table 1) could be best described by a third order polynomial function $(\mathrm{Y}=45.85-$ $0.46913 \mathrm{x}+0.00416 \mathrm{x}^{2}-0.00002 \mathrm{x}^{3} ; \mathrm{R}^{2}$ $=0.99$ ), showing that the decrease in seed moisture was faster at the beginning of the drying process, presented a steady decrease during the middle stage, then decreased rapidly after $20 \%$ seed moisture was reached. The drying process adopted here can be classified as slow drying (Pammenter $e t$ al., 1998), since it took 156 hours for the seed initial moisture (47.5\%) to drop to $15.1 \%$. Pammenter et al. (1998) stated that the drying rate of whole seeds could influence the response to desiccation, with rapidly dried seeds surviving lower moisture contents. Slow drying contributed to homogeneous dehydration, leading to considerable membrane degradation. In fact, membranes are particularly susceptible to damage during slow drying, because the degradative processes appears to be aqueous-based and oxidative in nature (Pammenter et al., 1998).

Seed moisture significantly influenced King palm germination and vigor. Seed germination progressively reduced as moisture content decreased (Table 1; Figure 1a). The decrease in normal seedlings was associated with a corresponding increase in dead seeds (Table 1). The critical water content was identified as $31.5 \%$ seed moisture and the lethal water content as $15.1 \%$. Nonetheless, care should be taken when specifying a value or range of values as critical moisture, below which significant germination rate reduction is observed. As stated by Pammenter et al. (1998), there are differential responses to dehydration at different drying rates, implying that it is not possible to define unambiguously a critical moisture content for viability loss by recalcitrant seeds. Studies at different drying rates should be done with King palm seeds, in order to verify if this is a valid statement.

The abnormal seedling percentage (Table 1) was larger in the intermediary moisture levels (31.5\% to $28.2 \%$ ). As seed deterioration advanced, caused by seed moistures below $28.2 \%$, the abnormal seedlings with superficial lesions died, causing reduction in this seedling type and an increase in dead seeds (Roberts, 1986). Several authors (Pammenter et al., 1991; Pritchard, 1991; Berjak \& Pammenter, 1997) reported that seeds dried at intermediate 
Table 2. Correlation coefficients and significance among traits evaluated during the King palm germination process $(n=56)$. Botucatu, UNESP, 1999.

\begin{tabular}{llllllll}
\hline \multirow{2}{*}{ Traits } & \multicolumn{7}{c}{ Correlation coefficients } \\
\cline { 2 - 7 } & FCG & DS & TG & AS & PL & RL & EC \\
\hline Seed moisture (SM) & $0.81^{* * *}$ & $-0.86^{* * *}$ & $0.87^{* * *}$ & $0.42^{* *}$ & $0.75^{* * *}$ & $0.83^{* * *}$ & $-0.78^{* * *}$ \\
First count (FCG) & & $-0.91^{* * *}$ & $0.90^{* * *}$ & $0.51^{* * *}$ & $0.65^{* * *}$ & $0.81^{* * *}$ & $-0.57^{* * *}$ \\
Dead seeds (DS) & & & $-0.97^{* * *}$ & $-0.63^{* * *}$ & $-0.67^{* * *}$ & $-0.78^{* * *}$ & $0.68^{* * *}$ \\
Total germination (TG) & & & & $0.43^{* * *}$ & $0.71^{* * *}$ & $0.80^{* * *}$ & $-0.68^{* * *}$ \\
Abnormal seedlings (AS) & & & & & $0.23 n s$ & $0.36^{* *}$ & $-0.38^{* *}$ \\
Plumule length (PL) & & & & & & $0.86^{* * *}$ & $-0.76^{* * *}$ \\
Radicule length (RL) & & & & & & & $-0.70^{* * *}$ \\
Electrical conductivity (EC) & & & & & & & \\
\hline
\end{tabular}

***,**, ns - Significant at $\mathrm{P}<0.001, \mathrm{P}<0.01$ and not significant.

moistures could suffer deleterious aqueous-based reactions, leading to poor germination rate and increased abnormal seedlings. Deterioration is a progressive and relentless process, acting on the seed metabolism through biochemical events, leading to membrane degradation and decreased biosynthetic reactions, which result in losses of several performance attributes, such as germination rate, field emergency, increase of abnormal seedlings and, finally, loss of the germination capacity (Roberts, 1986; Spears, 1995).

The vigor tests applied to King palm (first count germination, plumule and radicule length, and electrical conductivity) showed highly significant correlation coefficients when paired with seed moisture and total germination (Table 2), as well as among themselves. While first count germination and plumule and radicule length showed a positive relationship with seed moisture, the electrical conductivity presented a negative correlation (Table 2, and Figure 1b). Electrolyte leakage increased abruptly as seed were dried below the critical moisture and reaches its maximum value at lethal moisture, corroborating results observed by Walter-Vertucci et al. (1996) in Taxus brevifolia seeds and Martins et al. (1999c) in Euterpe edulis seeds.

The relationship between first count germination and seed moisture was best described by a logistic model equation $(\mathrm{Y}=58.97 /(1+14152.70 * \exp -0.32 \mathrm{x})$, with $\mathrm{R}^{2}=0.98$. First count germination rate decreased abruptly when the seed moisture dropped below $35 \%$.

Seedling growth rate, as expressed by plumule and radicule length (Table 1 ), was significantly lower for seeds with lower moisture (below 28.2\%) than seeds at optimum levels (47.5-34.6\%), corroborating the statement by Spears (1995) that seed vigor declines before decreases in viability are observed.

The progressive dehydration intensified the seed deterioration process, as indicated by final germination (Figure 1a) and vigor tests (Table 1, Figure 1b), establishing the recalcitrant behavior of King palm seeds. Similar results were obtained for other palm species (Ellis et al., 1991; Araújo et al., 1994; Andrade \& Pereira, 1997; Martins et al., 1999 ab).

The sensitivity of vigor tests is based on the identification of variables related to seed deterioration, which eventually results in loss of the germination capacity (the final stage of the deterioration process). The earlier the detection of seed deterioration, the higher the sensitivity of the test (Marcos Filho, 1999). Based on that criterion, the electrical conductivity test had the highest sensitivity, detecting a significant increase in conductivity when seed moisture dropped below $31.5 \%$. Moreover, compared to other vigor tests, it was the fastest and the easiest to apply. The differences in sensitivity found among vigor tests are expected, because they evaluated different aspects of seed physiology and the deterioration process. As pointed out by Marcos Filho (1999), the employment of several vigor tests is recommended in seed quality control.

The present study showed that seeds of King palm are recalcitrant, presenting the highest germination percentage when not dehydrated (initial moisture of $47.5 \%$ ). Below $31.5 \%$ seed moisture, the germination percentage and rate were significantly reduced, and total mortality was observed with seed dehydration below $17.8 \%$ moisture, indicating that seeds from that species should be sowed as soon as possible after harvesting. Electrolyte leakage measurement is recommended to evaluate the deterioration caused by dehydration of King palm seeds, because it was the most sensitive, easy to conduct and rapid of all the vigor tests evaluated.

\section{ACKNOWLEDGEMENTS}

The authors thank Dr. Charles R. Clement, Instituto Nacional de Pesquisas da Amazonia (INPA), for the revision of this paper.

\section{LITERATURE CITED}

ANDRADE, A.C.S.; PEREIRA, T.S. Comportamento de armazenamento de sementes de palmiteiro (Euterpe edulis Mart.) (Storage behavior of Euterpe edulis Mart. seeds). Pesquisa Agropecuária Brasileira, Brasília, v. 32, n. 10, p. 987-991, 1997.

ARAUJO, E.F.; SILVA, R.F.; ARAUJO, R.F. Avaliação da qualidade de sementes de açaí armazenadas em diferentes embalagens e ambientes (Quality evaluation of Euterpe oleracea Mart. seeds stored in different packages and conditions). Revista Brasileira de Sementes, v. 16, n. 1, p. 76-79, 1994. 
BERJAK, P.; PAMMENTER, N.W. Possible mechanisms underlying the differing dehydration responses in recalcitrant and orthodox seeds: desiccation-associated subcellular changes in propagules of Avicennia marina. Seed Science and Technology, v. 12, n. 2, p. 365-384, 1997.

BOVI, M.L.A. Cultivo da palmeira real australiana visando à produção de palmito. (Cultivation of alexandra palm aiming heart-ofpalm production). Campinas: Instituto Agronômico, 1998a. 26 p. (Boletim Técnico 172). BOVI, M.L.A. Palmito pupunha: informações básicas para cultivo (Peach palm: cultivation basic information). Campinas: Instituto Agronômico, 1998b. 50 p. (Boletim Técnico 172).

ELLIS, R.H.; HONG, T.D.; ROBERTS, E.H.; SOETISNA, U. Seed storage behaviour in Elaeis guineensis. Seed Science Research, v. 1, n. 1, p. 99-104, 1991

FERREIRA, S.A.N.; SANTOS, L.A. Viabilidade de sementes de pupunha (Bactris gasipaes Kunth.) (Peach palm seed viability). Acta Amazonica, v. 22, n. 3, p. 303-307, 1992.

HONG, T.D.; ELLIS, R.H. Optimum air-dry seed storage environments for arabica coffee. Seed Science and Technology, v. 20, n. 3, p. 547-560, 1992.

INTERNATIONAL SEED TESTING ASSOCIATION. International rules for seed testing. Rules 1993. Seed Science and Technology, v. 21, n. 1, p. 1-75, 1993.
MARCOS FILHO, J. Testes de vigor: importância e utilização (Vigor tests: importance and utilization). In: Krzyzanowski, F.C.; Vieira, R.D.; França Neto, J.B.(Eds.) Vigor de sementes, conceitos e testes (Seed vigor, concepts and tests). Londrina: ABRATES, 1999. p. 1-20.

MARTINS, C.C.; NAKAGAWA, J.; BOVI, M.L.A. Desiccation tolerance of four seedlots from Euterpe edulis Mart. Seed Science and Technology, v. 28, n. 1, p. 1-13, 1999a.

MARTINS, C.C.; NAKAGAWA, J.; BOVI, M.L.A. Tolerância à dessecação de sementes de palmito-vermelho (Euterpe espiritosantensis Fernandes). (Desiccation tolerance of Euterpe espiritosantensis seeds). Revista Brasileira de Botânica, v. 22, n. 3, p. 391-396, 1999b.

MARTINS, C.C.; NAKAGAWA, J.; BOVI, M.L.A. ; STANGUERLIM, H. Teores crítico e letal de água para sementes de açaizeiro (Euterpe oleracea Mart.). (Critical and lethal moisture of Euterpe oleracea seeds). Revista Brasileira de Sementes, v. 21, n. 1, p. 125-132, 1999c.

PAMMENTER, N.W.; VERTUCCI, C.W.; BERJAK, P. Homeohydrous (recalcitrant) seeds: dehydration, the state of water and viability characteristics in Landolphia kirkii. Plant Physiology, v. 96, n. 4, p. 1093-1098, 1991.

PAMMENTER, N.W.; GREGGAINS, V.; KIOKO, J.I.; WESLEY-SMITH, J.; BERJAK, P.; FINCH-SAVAGE, W.E. Effects of differential drying rates on viability retention of recalcitrant seeds of Ekebergia capensis. Seed Science Research, v. 8, n. 4, p. 463-471, 1998.
PAMMENTER, N.W.; BERJAK, P. A review of recalcitrant seed physiology in relation to desiccation-tolerance mechanisms. Seed Science Research, v. 9, n. 1, p. 13-37, 1999.

PRITCHARD, H.W. Water potential and embryonic axis viability in recalcitrant seeds of Quercus rubra. Annals of Botany, v. 67, n. 1, p. 43-49, 1991.

PROBERT, R.J.; LONGLEY, P.L. Recalcitrant seed storage physiology in three aquatic grasses (Zizania palustris, Spartina anglica and Portesia coarctata). Annals of Botany, v. 63, n. 1, p. 53-63, 1989.

ROBERTS, E.H. Quantifying seed deterioration. In: M.B. McDonald and C.J. Nelson, eds. Physiology of Seed Deterioration. Crop Science Society of America, Inc, Madison, p. 101-123, 1986.

SPEARS, J.F. An introduction to seed vigor testing. In: VAN DER VENTER, H.A., ed. Seed vigor testing seminar. International Seed Testing Association, Zürich, p.1-9, 1995.

WALTER-VERTUCCI, C.; CRANE, J.;VANCE, N.C. Physiological aspects of Taxus brevifolia seeds in relation to seed storage characteristics. Physiologia plantarum, v. 98, n. 1, p. 1-12, 1996. 